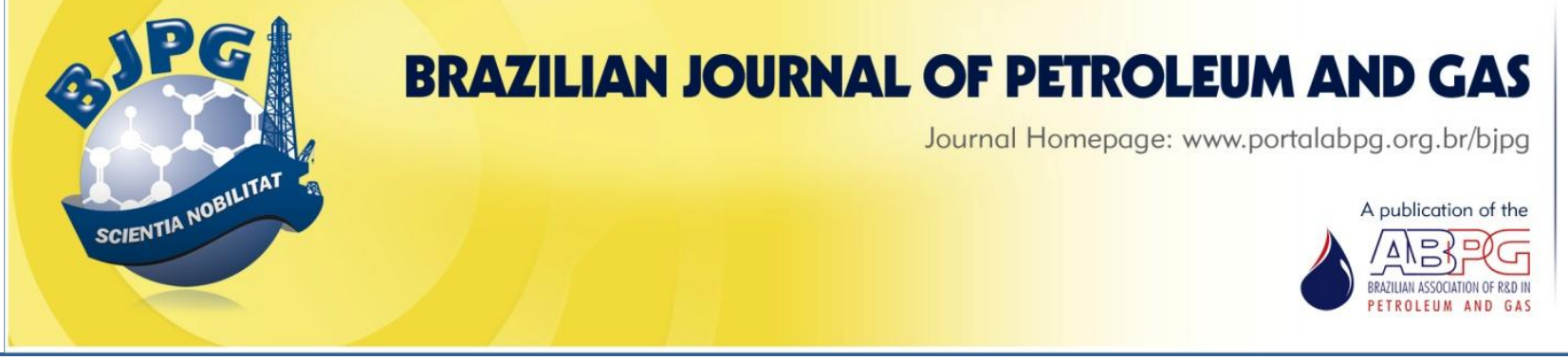

\title{
BIOGENIC PRODUCTION OF SULFIDES IN WATER-OIL SAMPLES AND ITS CORRELATION WITH THE DETERIORATION OF STORAGE TANKS
}

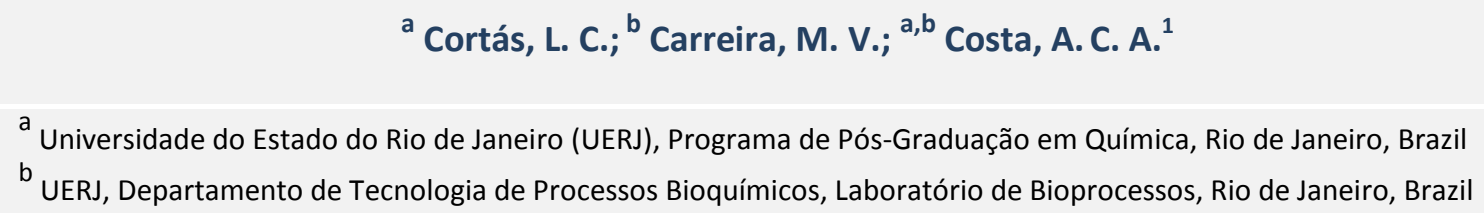

\begin{abstract}
Production of $\mathrm{H}_{2} \mathrm{~S}$ is one of the main problems in the petroleum industry and one of the leading causes of corrosion in storage tanks. The microbial species found in marine/oil environments and tanks include the general anaerobic heterotrophic bacteria (GAHB) and the sulfate-reducing bacteria (SRB). This research implemented a method based on the semi-continuous production of sulfide, over 15 days, in an attempt to make correlations between sulfide production and microbial quantification. Observation of the most suitable conditions for biogenic-sulfide production indicated that an increase in salinity and temperature produce a significant decrease in the semi-continuous biogenic production of sulfide. Dilution of the culture medium promoted a decrease in cell growth and production of sulfides. The quantification of SRB and GAHB was evaluated using the MPN (Most Probable Number) technique according to FDA regulations (Food and Drug Administration). The use of this procedure contributed to the increase in reliability coefficient used in the quantification data.
\end{abstract}

\section{KEYWORDS}

produced water; sulfate-reducing bacteria; sulfide; corrosion; storage tanks

\footnotetext{
${ }^{1}$ To whom all correspondence should be addressed.

Address: Universidade do Estado do Rio de Janeiro, Programa de Pós-Graduação em Química, R. São Francisco Xavier 524, Rio de Janeiro- Brazil - CEP 20550-013

Telephone / Fax: +55 21 2334-0563 | E-mail: acosta@uerj.br

doi:10.5419/bjpg2012-0010
} 


\section{INTRODUCTION}

In recent years, the injection of seawater during the process of secondary oil recovery has become more common as an attempt to increase the productivity of oil wells, thus, maintaining the reservoir's pressure and displacing the oil toward producing wells (Thomas et al., 2004). In a newly discovered oil field, the volume of water produced is small, representing approximately $5-15 \%$ of the volume produced. As the economic life of an oil well reaches its end, the volume of produced water can exceed the total volume of oil production (Shpiner et al., 2009).

During secondary oil recovery, the injection of seawater is responsible for the production of hydrogen sulfide $\left(\mathrm{H}_{2} \mathrm{~S}\right)$ due to the presence of SRB, causing a reduction of sulfate into sulfide. Intensive production of $\mathrm{H}_{2} \mathrm{~S}$ has been a major problem for the petroleum industry, as it represents a major cause of corrosion in production lines, water treatment systems, oil rigs, and accessory equipments (Penna et al., 2003). Thus, petroleum industries produce large quantities of oily wastewater, which present characteristics that are potentially dangerous to the environment. The combination of wastewater components, their volume, and the characteristics of the sites where such effluents are disposed of must be taken into account while assessing possible environmental impacts (Silva, 2000). The water produced in this process is treated as a form of waste. It accumulates in storage tanks for oil and water, which creates an environment that is favorable for the proliferation of microorganisms, especially SRB (Sant'Anna et al., 2008). SRB are microorganisms that carry out dissimilative reduction of the sulfate ion, acting as an oxidizing agent for the metabolism of organic matter, generating $\mathrm{H}_{2} \mathrm{~S}$ as well as high toxicity, and corrosive power (Postgate, 1984). Understanding SRB's activity is of great interest to industry, particularly for the oil and oiltransportation sector, which are affected greatly by the corrosion associated with these microorganisms.

The novelty of this research resides on the investigation of water-oil samples and their potential corrosive properties based on the evaluation of optimum conditions for sulfide biogenic production. Conventionally, this evaluation is performed based on the quantification of the microbial groups involved, particularly the sulfate-reducing bacteria. This conventional method is not always the best parameter to be used due to the different metabolic states of the cells, which are not correlated directly with sulfide production.

The water produced during oil recovery generally contains high salinity levels and has oil particles in suspension as well as chemicals, heavy metals, and bacteria that cause corrosion via metabolites. Thus, significant volumes of this form of waste become difficult to dispose of, contributing to the increase in pollution. Therefore, this study was performed to analyze the production of $\mathrm{H}_{2} \mathrm{~S}$ associated with water production from oil storage tanks and with water in which a microbial consortium has formed inside a tank, resulting in the generation of $\mathrm{H}_{2} \mathrm{~S}$ through the metabolism of SRB. The aim of this study was to evaluate the main parameters that contribute to the production of biogenic sulfide in real samples from water-oil storage tanks.

\section{MATERIALS AND METHODS}

\subsection{Modified Postgate E medium for SRB}

The medium used for the detection and quantification of SRB was the Postgate Medium E (Table1) (Postgate, 1984). The pH was adjusted to 7.6 with $0.1 \mathrm{M}$ of $\mathrm{NaOH}$ (Merck, 97\%). After preparation of the medium, it was distributed in $9.0 \mathrm{~mL}$ penicillin flasks, which were then sealed. The flasks were sterilized for 20 minutes at $121^{\circ} \mathrm{C}$. A redox potential of $-100 \mathrm{mV}$ was used with $0.1 \mathrm{~mL}$ of a solution of $12.4 \mathrm{~g} / \mathrm{L}$ sodium thioglycollate (Merck, 99\%).

\subsection{Postgate C medium for SRB}

The culture medium used to grow SRB was the Postgate Medium C (Postgate, 1984). The preparation of this medium is similar to the Postgate Medium E, except for the volume added to the vials, which was $45.0 \mathrm{~mL}$ (Table 1 ).

\subsection{Culture medium for GAHB}

The composition of the medium for the detection and quantification of GAHB is shown in Table2. The $\mathrm{pH}$ was adjusted to 7.6. After 
Table 1. Composition of Modified Postgate E and Postgate C Media (1.0L).

\begin{tabular}{lcc}
\hline & Postgate E & Postgate C \\
\cline { 2 - 3 } \multicolumn{1}{c}{ Component } & \multicolumn{2}{c}{ Quantity } \\
\cline { 2 - 3 } Potassium phosphate, Isofarma, 99\% & $0.5 \mathrm{~g}$ & $0.5 \mathrm{~g}$ \\
Ammonium chloride, Merck, 99.9\% & $1.0 \mathrm{~g}$ & $1.0 \mathrm{~g}$ \\
Sodium sulfate, Sigma, 99\% & $1.0 \mathrm{~g}$ & $4.5 \mathrm{~g}$ \\
Calcium chloride, Merck, 99.9\% & $0.6 \mathrm{~g}$ & $0.040 \mathrm{~g}$ \\
Magnesium chloride, Merck, P.A. & $1.83 \mathrm{~g}$ & $0.06 \mathrm{~g}$ \\
Sodium lactate (50\% m/v), Sigma-Aldrich, >99\% & $7.0 \mathrm{~mL}$ & $9.4 \mathrm{~mL}$ \\
Yeast extract, Merck, 97\% & $1.0 \mathrm{~g}$ & $1.0 \mathrm{~g}$ \\
Ascorbic acid, Vetec, P.A. & $0.1 \mathrm{~g}$ & $0.1 \mathrm{~g}$ \\
Ferrous sulfate, Vetec, P.A. & $0.5 \mathrm{~g}$ & $0.04 \mathrm{~g}$ \\
Agar-Agar, Merck, P.A. & $1.9 \mathrm{~g}$ & $1.9 \mathrm{~g}$ \\
Resazurin (0.025\% m/v), Merck, High Purity & $4.0 \mathrm{~mL}$ & $4.0 \mathrm{~mL}$ \\
Sodium chloride, Merck, P.A. & $35 \mathrm{~g}$ & $35 \mathrm{~g}$ \\
Sodium citrate, Merck, P.A. & - & $0.3 \mathrm{~g}$ \\
\hline
\end{tabular}

Table 2. Composition of the medium for GAHB (1.0 L).

\begin{tabular}{lc}
\hline Component & Quantity \\
\hline Glucose, Merck, P.A. & $5.0 \mathrm{~g}$ \\
Peptone, Merck, P.A. & $4.0 \mathrm{~g}$ \\
Yeast Extract, Merck, 97\% & $1.0 \mathrm{~g}$ \\
Resazurin (0.025\% m/v), Merck, High Purity & $4.0 \mathrm{~mL}$ \\
Sodium chloride, Merck, P.A. & $3 \mathrm{~g}$ \\
\hline
\end{tabular}

preparation of the medium, it was distributed in $9.0 \mathrm{~mL}$ volumes into $10.0 \mathrm{~mL}$ bottles, which were subsequently sealed with rubber stoppers and an aluminum seal. Then, the flasks containing the medium were sterilized for 20 minutes at $121^{\circ} \mathrm{C}$. After cooling, thioglycollate was also added to reduce the redox potential of the medium.

\subsection{Solution for dilution of SRB and GAHB media}

The composition of the reducing solution used in dilutions of the SRB and GAHB media is presented in Table 2, the same used for GAHB cultivation. After preparation of this solution, the $\mathrm{pH}$ was adjusted to 7.6. Anaerobic conditions were created and distribution was performed as previously described. The flasks were autoclaved at $121^{\circ} \mathrm{C}$ for 20 minutes.

\subsection{Synthetic seawater}

To prepare the seawater, six solutions were prepared and, subsequently, mixed to obtain a final volume of $5 \mathrm{~L}$. This later solution was stirred for $24 \mathrm{~h}$ and, then, filtered through a $0.45 \mu \mathrm{M}$ membrane prior to storage (Table3).

\subsection{Quantification of SRB and GAHB cells}

The quantification of the bacterial populations present in the samples was performed using the Most Probable Number technique (MPN) (McCrady, 1915). MPN is a technique that allows estimation of the bacterial density in a sample through positive and negative results in a series of successive dilutions and multiple tubes. This method assumes that bacteria are typically distributed in the liquid medium, and that the number of microorganisms in the samples measured is equal for samples subjected to the same kind of processing. The dilutions ranged from $10^{0}$ to $10^{8}$. The flasks were incubated with the samples for 28 days in an oven (Nova Ética, Model D411) at $30^{\circ} \mathrm{C}$. Bacterial growth was monitored and quantified according to the procedure proposed by Harrigan (1998). 
Table 3. Composition of synthetic seawater.

\begin{tabular}{lc}
\hline Component & Quantity \\
\hline Solution 1 & \\
\hline Strontium chloride & $0.10 \mathrm{~g}$ \\
Borax & $0.15 \mathrm{~g}$ \\
Potassium bromide & $0.5 \mathrm{~g}$ \\
Potassium chloride & $3.5 \mathrm{~g}$ \\
Distilled water & $500 \mathrm{~mL}$ \\
\hline Solution 2 & \\
\hline Calcium chloride & $5.56 \mathrm{~g}$ \\
Distilled water & $1000 \mathrm{~mL}$ \\
\hline Solution 3 & \\
\hline Sodium sulfate & $20.0 \mathrm{~g}$ \\
Distilled water & $1000 \mathrm{~mL}$ \\
\hline Solution 4 & \\
\hline Magnesium chloride & $53.90 \mathrm{~g}$ \\
Distilled water & $500 \mathrm{~mL}$ \\
\hline Solution 5 & \\
\hline Sodium chloride & $117.5 \mathrm{~g}$ \\
Distilled water & $1000 \mathrm{~mL}$ \\
\hline Solution 6 & \\
\hline Sodium silicate & $0.10 \mathrm{~g}$ \\
Sodium EDTA & $0.05 \mathrm{~g}$ \\
Sodium carbonate & $1.00 \mathrm{~g}$ \\
Distilled water & $1000 \mathrm{~mL}$ \\
\hline
\end{tabular}

In the SRB growth medium, positivity is indicated by the presence of a black precipitate of iron sulfide resulting from the reduction of sulfate to sulfide, which reacts with the $\mathrm{Fe}^{+2}$ present in the medium. For GAHB, positivity is indicated by turbidity and discoloration in the culture medium.

The microbial populations of SRB and GAHB were quantified by both MPN according to Harrigan (1998) and according to the procedure proposed by the FDA (2011). This procedure assumes that the distribution of microbial populations measured by MPN is not a statistically normal distribution. It takes into account the distribuition's lower and upper bounds, providing statistical significance for the evaluation.

\subsection{Quantification of total sulfides}

The total concentration of sulfide present in the sample was measured spectrophotometrically with methylene blue:

Step 1: Injection of $\mathrm{N}_{2}$ to expel $\mathrm{H}_{2} \mathrm{~S}$ by precipitation as cadmium sulfide. In this step, the sample was purged with nitrogen at a rate of $100 \mathrm{~mL} / \mathrm{min}$ for 30 minutes. A needle was inserted within the sample, and a plastic catheter was introduced to collect the output of $\mathrm{H}_{2} \mathrm{~S}$ released by the SRB into the sample. The entrained $\mathrm{H}_{2} \mathrm{~S}$ was collected using a system comprised of an absorption impinger bottle containing $50.0 \mathrm{~mL}$ of a solution of cadmium sulfate in alkaline medium under refrigeration and in absence of light. The sulfide reacted with the cadmium, forming a yellow precipitate.

Step 2: Quantification of $\mathrm{H}_{2} \mathrm{~S}$ by spectrophotometry. The $\mathrm{H}_{2} \mathrm{~S}$ precipitated as cadmium sulfide and was released in an acid medium through reaction with $\mathrm{N}, \mathrm{N}$-dimethyl-pdiphenylamine with a ferric chloride catalyst to forma core of methylene blue. Absorbance was measured after 20 minutes at $670 \mathrm{~nm}$ in a spectrophotometer (AnalytkjenaSpecord50). Using this technique, it was possible to achieve linearity between the absorbance measurements (between 0.0056 and 0.57 ) and the mass of $\mathrm{H}_{2} \mathrm{~S}$ (between 0.2 $\mathrm{mg}$ and $12.0 \mathrm{mg}$ ) with an optical path of $10 \mathrm{~mm}$ (APHA, 1998).

\subsection{Semicontinuous biogenic activity (SBA)}

These assays were performed in a semicontinuous system to minimize the effect of the accumulation of metabolic products on the growth medium (Postgate, 1984):

- Inoculation of $5.0 \mathrm{~mL}$ of the sample into Postgate C medium was performed, followed by incubation in a greenhouse for 15 days.

- Over the 15 -day period (360 hours), the $\mathrm{H}_{2} \mathrm{~S}$ produced was washed in accordance with the step described for the determination of total sulfides. This allowed evaluation of the concentration profile of sulfide accumulation is indicative of the potential of the sample to produce biogenic sulfides, which in turn is related to bacterial activity.

\subsection{Parameters affecting SBA}

\subsubsection{Evaluation of microbiological contamination in three tanks}

Samples were analyzed from three storage tanks for water and oil, designated A, B, and C. The 
samples were incubated at $30^{\circ} \mathrm{C}$ in a salinity of $35 \mathrm{~g} / \mathrm{L}$ (sea water) in culture media suitable for SRB or GAHB. The quantification of the total sulfide in the samples was carried out using SBA, as previously described. The purpose of this evaluation was to examine microbiological contamination for the purpose of selecting the most contaminated tank to study the main parameters that influence the production of biogenic sulfides. All the experiments in this set were conducted in triplicate and average results were reported.

\subsubsection{Effect of salinity on the generation of biogenic sulfides}

Using samples from the tank selected in the previous step, different salinity conditions $(40 \mathrm{~g} / \mathrm{L}$, $45 \mathrm{~g} / \mathrm{L}, 50 \mathrm{~g} / \mathrm{L}$, and $70 \mathrm{~g} / \mathrm{L}$ ) were tested to determine the growth of SRB and GAHB and the generation of sulfide in the sample using the SBA methodology. These salinities were selected in this stage because they are typical of the marine environment. Water storage tanks were collected after the production processes and following the water injection for the secondary recovery of oil.

\subsubsection{Effect of temperature on biogenic sulfide generation}

Using the salinity selected in the previous section, the samples were tested at different temperatures: $30^{\circ} \mathrm{C}, 40^{\circ} \mathrm{C}, 50^{\circ} \mathrm{C}$, and $60^{\circ} \mathrm{C}$. At this stage, the previously described parameters were monitored. These temperatures were selected based on the occurrence of sulfate-reducing bacteria and anaerobic bacteria, rather than the total heterotrophic mesophilic range.

\subsubsection{Effect of the composition of the medium on biogenic sulfide generation}

Using the conditions of salinity and temperature selected to promote bacterial growth and biogenic sulfide generation, the use of the culture medium in different proportions was also analyzed. The culture medium composition was: saline alone (synthetic sea water with no organic nutrients) and with $10 \%, 25 \%$, and $50 \%$ of the composition of the original culture medium. The same parameters were monitored during this phase. The objective was to establish conditions for a more conservative biogenic sulfide generation because under optimized conditions, the biogenic production of sulfide could be stimulated by the presence of nutrients essential to the metabolism of the bacteria. However, in storage tanks for water-oil or the marine environment, the availability of organic matter is not equivalent to that found in the culture medium employed here. Therefore, the experiment gradually diluted the culture medium, aiming at achieving physical and chemical conditions closer to those of the storage tanks. The previously described parameters were also monitored in this case.

\section{RESULTS AND DISCUSSION}

\subsection{Selection of the tank with the highest SBA}

Figure 1 shows the results of the determination of the concentration of sulfide in the samples from the selected tanks as a function of time.

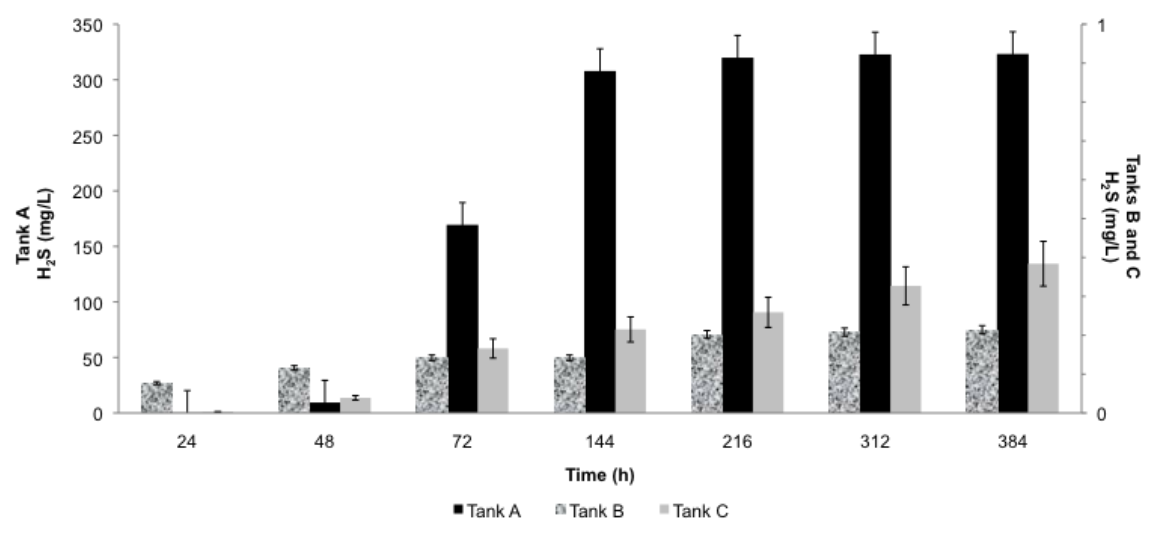

Figure 1. Evaluation of SBA in samples from the water-oil storage tanks for quantification of the formation of biogenic sulfide. 
Figure 1 depicts the profiles of the biogenic production of sulfide measured in samples from tanks A, B, and C. It can be observed that the sample with the highest concentration of total sulfide, monitored over time, came from tank A. This sample contained sulfides at a concentration of $169 \mathrm{mg} / \mathrm{L}$ after 72 hours, which reached $308 \mathrm{mg} / \mathrm{L}$ after 144 hours and peaked at $323 \mathrm{mg} / \mathrm{L}$ at the end of the monitoring period. In the samples from tanks B and C, the concentrations of sulfide were considerably lower, peaking at $0.2 \mathrm{mg} / \mathrm{L}$ and $0.4 \mathrm{mg} / \mathrm{L}$, respectively. When considering the presence of sulfate, it must be taken into account that it is soluble in the sample. The sulfate may be of microbial origin or not, as these storage tanks hold contents other than produced water collected following injection procedures. In addition, the sulfide formed by microbes can also be transferred to the environment in the form of $\mathrm{H}_{2} \mathrm{~S}$, which can mask the true concentration of sulfide formed by the SRB present in the tanks. Therefore, the experiment assessed the semi-continuous biogenic activity (SBA) to determine the true potential of these bacteria to form biogenic sulfide under varying conditions of parameters that regulate microbial activity.

The biogenic activities were considered to represent the production of biogenic sulfide accumulated over a period of 15 days with periodic release of sulfide. The observation of the sample from this tank shows that the concentration of sulfide only reaches a significant level after approximately 72 hours of incubation. It is likely that this period must coincide with the lag phase in the growth of microorganisms within the tank, which is an adjustment period associated with little generation of metabolites, intense synthesis of enzymes, and physiological adaptation to accelerated growth (Madigan et al., 2010). The correlation of the results with the lag phase becomes interesting with respect to understanding why the numbers of microbial groups, alone, are not the most appropriate parameter to describe the state of contamination within a tank. The correlation of the quantification of sulfides with the concentrations of SRB and GAHB might indicate that microbial activity is not always linked directly to the production of sulfides.

After the lag phase, increasing sulfide formation can be observed, resulting from the metabolism of the SRB in the water sample introduced into the culture medium. As sulfide is periodically drawn from the medium to be measured in regular time intervals, the toxic effect of this metabolite becomes minimized, and the reduction of sulfate in the medium is facilitated by the reduction of microbial inhibition among the SRB due to the presence of sulfide. The first measurement of sulfide, performed after the lag phase, indicated a concentration of approximately $169 \mathrm{mg} / \mathrm{L}$, indicating the potential generation of sulfide by the SRB in the tank at the beginning of testing. This first increase in the formation of sulfide indicates a high level of adaptation related to the onset of the exponential phase of microbial growth, associated with the production of sulfide. The presence of sulfide in the samples from the tanks results in corrosion of the metal structure of the tank because the $\mathrm{H}_{2} \mathrm{~S}$ produced by the SRB is a strong corrosive agent of these structures (Videla, 2003).

In a study performed by Penna et al. (2003), the authors evaluated four different inocula in cultures prepared in culture media containing different amounts of synthetic sea water and formation water from the Marlin Field, Brazil. The media were incubated for 28 days at a temperature of $35^{\circ} \mathrm{C}$ and analyzed for sulfide-generating activities. In the medium associated with the highest production of sulfide, $220 \mathrm{mg} / \mathrm{L}$ of sulfide was generated in 28 days. Comparing this result with the results obtained in the present study, in the sample from the investigated tank, it was observed that in just 384 hours (16 days), the sulfide concentration reached $323 \mathrm{mg} / \mathrm{L}$. This indicates that the sample came from a tank with a high degree of contamination, or with a high potential production of biogenic sulfide. It can be observed in Figure 1 that there is a clear trend for a stationary phase of microbial growth represented by the formation of sulfides. According to the characteristics previously presented, the sample of water from tank $A$ was selected for further testing. As the samples from Tanks $B$ and $C$ showed concentrations near the detection limit, they were discarded from further analyses.

Quantification of microbiological MPN using the procedures proposed by Harrigan (1998) and by the Food and Drug Administration (FDA, 2011) is presented in Table 4, showing the results obtained for the quantification of SRB in the 3 studied tanks. 
Table 4. Quantification of SRB cell numbers in tanks A, B and C.

\begin{tabular}{ccccc}
\hline \multicolumn{5}{c}{ MPN (MPN/mL) - SRB } \\
\hline \multirow{2}{*}{ Tank } & \multirow{4}{*}{ Harrigan } & \multicolumn{4}{c}{ FDA } \\
\cline { 3 - 5 } & & Value & Minimum value & Maximum value \\
\hline A & $4.50 \times 10^{5}$ & $6.82 \times 10^{8}$ & $3.26 \times 10^{8}$ & $1.43 \times 10^{9}$ \\
B & 0.4 & 0.36 & 0.05 & 2.58 \\
C & 0 & 0 & 0 & 0 \\
\hline
\end{tabular}

Table 5. Quantification of GAHB cells in tanks A, B and C.

\begin{tabular}{ccccc}
\hline \multicolumn{5}{c}{ MPN (MPN/mL) - GAHB } \\
\hline \multirow{2}{*}{ Tank Harrigan } & \multicolumn{4}{c}{ FDA } \\
\cline { 3 - 5 } & & Value & Minimum value & Maximum value \\
\hline A & $4.50 \times 10^{6}$ & $2.51 \times 10^{10}$ & $1.30 \times 10^{10}$ & $4.87 \times 10^{10}$ \\
B & $2.00 \times 10^{4}$ & $2.98 \times 10^{7}$ & $1.52 \times 10^{7}$ & $5.84 \times 10^{7}$ \\
C & $9.50 \times 10^{5}$ & $9.50 \times 10^{8}$ & $4.72 \times 10^{8}$ & $1.92 \times 10^{9}$ \\
\hline
\end{tabular}

Table 4 shows that only the microbial numbers in tank $A$ were statistically significant, based on both the Harrigan $\left(4.50 \times 10^{5} \mathrm{MPN} / \mathrm{mL}\right)$ and FDA methods $\left(6.82 \times 10^{8} \mathrm{MPN} / \mathrm{mL}\right)$. It should be noted that the value estimated according to Harrigan (1998) was significantly lower than that estimated by the FDA method (2011). This indicates that the measurements performed following Harrigan (1998) underestimate the microbial population in this type of environmental sample, considering only its absolute value. The measurements also disregard the lower and upper limits specified in the MPN method and considered by the FDA (2011). These results corroborate the data obtained from the quantification of sulfide accumulation, which also indicated a substantial concentration of sulfide only in tank A. Tanks B and $C$ showed a low concentration of cells, which confirms the finding that the production of sulfides is negligible. Thus, it can be observed that there is a correlation between the production of the microbial population and sulfides, and that both can be used to evaluate biogenic activity in water and oil tanks.

Agrawal et al. (2010) studied the SRB in two tanks containing separated water and oil mixtures. Samples from these tanks were inoculated in media selective for the growth of SRB, and after 28 days of incubation, there was an increase of approximately $10^{5} \mathrm{MPN} / \mathrm{mL}$. This study aimed to demonstrate the diversity of the bacteria present in the pond and the problems associated with corrosion in tanks generated by the souring of separated oil and water. Thus, it can be stated that the population of SRB in the samples analyzed by Agrawal et al. (2010) presented concentrations equivalent to those found in this study. However, these authors did not mention biogenic sulfide production. Table 5 shows the results obtained for the quantification of GAHB samples from the three tanks, A, B, and C, using the procedures proposed by Harrigan (1998) and the Food and Drug Administration (FDA, 2011).

Table 5 shows that there was a substantial growth of GAHB in the 3 tanks. Similarly to what was previously observed, the values predicted by Harrigan (1998) were, again, lower than those obtained based on the FDA method (2011). The disparity in these results warn that absolute values should not be used and that the limits that provide better statistical reliability to the results should be considered.

Studies conducted by Vieira et al. (2011) aimed to verify microbiological contamination in water oil production. The authors noted the presence of considerable numbers of anaerobic bacteria in the produced water, indicating the possibility that these microorganisms could produce metabolites 


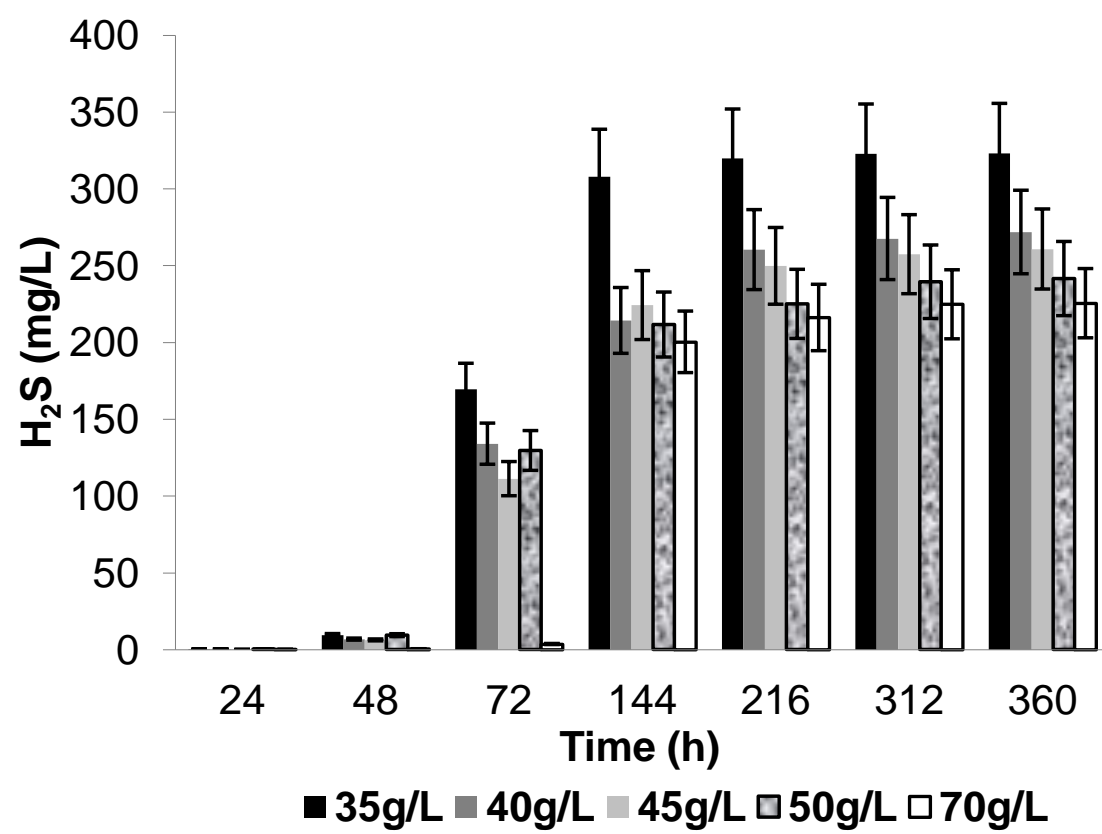

Figure 2. SBA in Tank A with different salinities.

leading to the growth of SRB. These authors used the MPN method and a Postgate medium, with incubation at $30^{\circ} \mathrm{C}$ for 28 days. The total number of anaerobic bacteria was $2.5 \times 10^{4} \mathrm{MPN} / \mathrm{mL}$, while SRB were more abundant, at $9.5 \times 10^{5} \mathrm{MPN} / \mathrm{mL}$. These results are in accordance with those of the present work, where, in the case of SRB, microbial populations on the same order of magnitude were found according to the method proposed by Harrigan (1998). GAHB showed a similar value (2.0 $x 10^{4} \mathrm{MPN} / \mathrm{mL}$ ) in only one of the investigated tanks. In the other 2 tanks, the values found for GAHB were higher $\left(4.5 \times 10^{6}\right.$ and $9.5 \times$ $10^{5} \mathrm{MPN} / \mathrm{mL}$ ). The GAHB are important members of the microbial consortium formed because organic substances of low molecular weight excreted by GAHB are used by SRB as an energy source (Vazoller, 1993). Again, the population measured in the tank $A$ was higher than the populations quantified in Tanks B and C. One explanation for this may be related to the availability of low molecular weight organic matter for bacteria in addition to SRB, resulting in the low population density of SRB in tanks $B$ and $C$, despite the high GAHB population densities. This indicates that the nature of the organic matter present determines the behavior in each particular tank. This leads to important conclusions regarding the behavior of these samples, such as that microbiological quantification over time without correlation with the formation of sulfides may be safe for explaining the behavior of a tank. There may be a large microbial population; however, depending on the charge present in the sample, there may be negligible production of sulfides. Thus, over the course of production, sulfide is a key parameter related to microbiological quantification. A large microbial population is not always indicative of a high degree of sulfide contamination, depending on the physiological state of the cells present.

Based on the results presented, it can be observed that the tank exhibited high microbial contamination of both SRB and GAHB as well as an increased production of biogenic sulfide. It was also observed that there is not always a direct correlation between microbial populations and biogenic sulfide production.

\subsection{Effect of salinity on the generation of biogenic sulfides}

The sample from tank $A$ was evaluated based on the growth of SRB, GAHB, and SBA at different salinities ranging from 35 to $70 \mathrm{~g} / \mathrm{L}$. These values were chosen to characterize the salinities of the marine environment and of the injection water. Figure 2 shows the concentration of sulfide produced by SRB under various salinities. 
Table 6. Quantification of SRB cells under different salinities.

\begin{tabular}{ccccc}
\hline \multicolumn{5}{c}{ MPN (MPN/mL) - SRB } \\
\hline \multirow{2}{*}{ Salinity } & Harrigan & \multicolumn{4}{c}{ FDA } \\
\cline { 3 - 5 } & & Value & Minimum value & Maximum value \\
\hline $35 \mathrm{~g} / \mathrm{L}$ & $4.50 \times 10^{5}$ & $6.82 \times 10^{8}$ & $3.26 \times 10^{8}$ & $1.43 \times 10^{9}$ \\
$40 \mathrm{~g} / \mathrm{L}$ & $9.50 \times 10^{6}$ & $3.49 \times 10^{10}$ & $1.83 \times 10^{10}$ & $6.69 \times 10^{10}$ \\
$45 \mathrm{~g} / \mathrm{L}$ & $2.50 \times 10^{6}$ & $2.00 \times 10^{10}$ & $1.01 \times 10^{10}$ & $3.98 \times 10^{10}$ \\
$50 \mathrm{~g} / \mathrm{L}$ & $2.00 \times 10^{6}$ & $1.13 \times 10^{9}$ & $6.05 \times 10^{8}$ & $2.13 \times 10^{9}$ \\
$70 \mathrm{~g} / \mathrm{L}$ & $4.50 \times 10^{5}$ & $7.19 \times 10^{8}$ & $3.60 \times 10^{8}$ & $1.44 \times 10^{9}$ \\
\hline
\end{tabular}

Results show that there was a similar profile in all of the chosen salinities. Increased production of sulfide occurred after 48 hours and remained nearly constant between 216 to 360 hours. In general, an increase in salinity contributes to decreasing the concentration of sulfides, indicating that salinity negatively affects biological activity related to forming sulfides. The salinity associated with the highest SBA was $35 \mathrm{~g} / \mathrm{L}$, which was the lowest salinity tested, typical of seawater. There was a considerable production of sulfide, even at the highest salinities tested. In a study performed by Brandt et al. (2001), it was observed that the rate of sulfate reduction increases when the salinity of the medium decreases. The highest salinities under which reduction of microbial sulfate was still observed were of $10-15 \% \mathrm{NaCl}$. Under these conditions, halophilic bacteria were able to survive salt stress.

Grassia et al. (1996) evaluated the thermophilic microorganisms present in the produced water from 36 oil reservoirs at high temperatures. They found that it was possible to observe the growth of strains that could be categorized into 3 different groups according to the depth of the reservoir (396- $3048 \mathrm{~m})$, temperature $\left(21-130^{\circ} \mathrm{C}\right)$, salinity range $(2.8-128 \mathrm{~g} / \mathrm{L})$, and $\mathrm{pH}$ range $(6.0-8.5)$. The microorganisms were isolated according to the salinity of the water. Group 1 included microorganisms from the genera Thermoanaerobacter and Thermoanerobacterium, associated with a salinity of approximately $30 \mathrm{~g} / \mathrm{L}$, as well as SRB. Groups 2 and 3 contained Thermotogales and Thermococcus. This study also showed that the isolation of thermophile microorganisms associated with the fermentation of oil reservoirs decreased with increasing temperatures and salinities. Similarly, the present study observed that the highest production of sulfide happened at the lowest salinity tested $(35 \mathrm{~g} / \mathrm{L})$ and that a reduction of microbial growth occurred with an increase in temperature, as will be shown in the next section.

\subsection{Microbiological quantification based on the procedures suggested by Harrigan (1998) and the FDA (2011)}

Table 6 presents the results of the MPN analysis of SRB at the different salinities assessed in the sample from tank $A$.

The results shown in Table 6 indicate that at all of the tested salinity values were lower than those measured using the statistical table proposed by the FDA (2011). This indication was based on the quantification results obtained using the MPN technique, considering the estimation procedure proposed by Harrigan (1998). Considering measurements performed in accordance with the FDA, there is an increase in the SRB population with an increase in salinity from 35 to $40 \mathrm{~g} / \mathrm{L}$. Increasing the salinity further to $45 \mathrm{~g} / \mathrm{L}$ does not change the microbial population as well as rising the salinity to $50 \mathrm{~g} / \mathrm{L}$ and $70 \mathrm{~g} / \mathrm{L}$, considering the lower and upper limits of each measurement. Thus, based on the FDA Table, a change in salinity from 40 to $70 \mathrm{~g} / \mathrm{L}$ does not contribute significantly to an increase in the population of SRB. In light of the results predicted by Harrigan (1998), it can be stated that there is an increase in the absolute population with an increase in the salinity from 35 to $40 \mathrm{~g} / \mathrm{L}$. However, the lack of upper and lower limits for each outcome does not allow precise conclusions to be drawn based on Harrigan's 
Table 7. Quantification of GAHB cells under different salinities.

\begin{tabular}{ccccc}
\hline \multicolumn{5}{c}{ MPN (MPN/mL) - GAHB } \\
\hline \multirow{2}{*}{ Salinity } & Harrigan & \multicolumn{3}{c}{ FDA } \\
\cline { 3 - 5 } & & Value & Minimum value & Maximum value \\
\hline $35 \mathrm{~g} / \mathrm{L}$ & $4.50 \times 10^{6}$ & $2.51 \times 10^{10}$ & $1.30 \times 10^{10}$ & $4.87 \times 10^{10}$ \\
$40 \mathrm{~g} / \mathrm{L}$ & $2.50 \times 10^{6}$ & $2.00 \times 10^{10}$ & $1.01 \times 10^{10}$ & $3.98 \times 10^{10}$ \\
$45 \mathrm{~g} / \mathrm{L}$ & $9.50 \times 10^{5}$ & $9.50 \times 10^{8}$ & $4.72 \times 10^{8}$ & $1.92 \times 10^{9}$ \\
$50 \mathrm{~g} / \mathrm{L}$ & $4.50 \times 10^{5}$ & $6.82 \times 10^{8}$ & $3.26 \times 10^{8}$ & $1.43 \times 10^{9}$ \\
$70 \mathrm{~g} / \mathrm{L}$ & $9.50 \times 10^{6}$ & $3.49 \times 10^{10}$ & $1.83 \times 10^{10}$ & $6.69 \times 10^{10}$ \\
\hline
\end{tabular}

method (1998). The values expressed using absolute values based on Harrigan (1998) are an order of magnitude lower than those obtained using the method proposed by the FDA (2011). This may occur because an assessment is used without taking into account the limits and the random errors occurring in the trial, when following Harrigan (1998), which leads to an underestimated quantification. Table 8 presents the data obtained for the MPN of GAHB based on both techniques.

The results presented in Table 7 show that at all of the tested salinities, the values obtained from the quantified Harrigan Table are an order of magnitude lower than those obtained using the FDA Table, as previously noted. Considering the measurements based on the Harrigan Table, it appears that there is no significant variation in the microbial population with an increase of salinity, which is also shown in the FDA Table, where an increase in salinity from 35 to $70 \mathrm{~g} / \mathrm{L}$ did not contribute significantly to the increase in the GAHB population. The values obtained at salinities of $35 \mathrm{~g} / \mathrm{L}$ and $40 \mathrm{~g} / \mathrm{L}$ were statistically equal.

According to Andrade et al. (2002), in bottom residue from a chiller to which a low concentration of corrosion inhibitor had been added, GAHB were observed at a high concentration $\left(5.4 \times 10^{5} \mathrm{MPN} / \mathrm{g}\right)$. As the tolerated salt level in produced water was up to $412 \mathrm{mg} / \mathrm{L} \mathrm{NaCl}$, it is assumed that the effectiveness of the corrosion inhibitor decreases with the increase in chloride. The correction of the inhibitor was not performed when the salinity of the water increased.

These authors warn that species of bacteria (SRB and GAHB) operate synergistically to create and maintain ideal conditions for the growth of each group. It can be concluded that based on measurements of SRB (FDA), the salinity that most favors the growth of this microbial group is the $40 \mathrm{~g} / \mathrm{L}$ one. Considering the results of the GAHB quantification (FDA), it can be concluded that a salinity of $35 \mathrm{~g} / \mathrm{L}$ is the most favorable for the proliferation of this microbial group. However, based on SBA, the negative effect of salinity on biogenic sulfide production is evident, regardless of the fact that the SRB population increased in tests with increasing salinities ranging from $35 \mathrm{~g} / \mathrm{L}$ to $40 \mathrm{~g} / \mathrm{L}$ in MPN. This indicates that the SBA results represent more reliable parameters than microbiological measurements. The SBA provides a direct product of the metabolism of microbial groups. It is associated with a low detection limit, but without the limitations of large oscillations resulting from the limits of quantification. Similarly to the previous results, it was selected a salinity of $35 \mathrm{~g} / \mathrm{L}$. For subsequent analyses, it was observed that this salinity increased the production of biogenic sulfide, which is a decisive parameter related to reliable growth and to the yield of metabolites.

\subsection{Effect of temperature on the generation of biogenic sulfides}

In Figure 3, the concentrations of sulfides produced by SRB over time at different temperatures can be evaluated.

A great influence of temperature on the production of sulfide can be observed. It is noted that as the temperature increases, the metabolic ability of SRB cells decreases. The lowest temperature $\left(30^{\circ} \mathrm{C}\right)$ was associated with a high production of $\mathrm{H}_{2} \mathrm{~S}$, beginning at 72 hours. It can be noted that a concentration greater than $150 \mathrm{mg} / \mathrm{L}$ is 


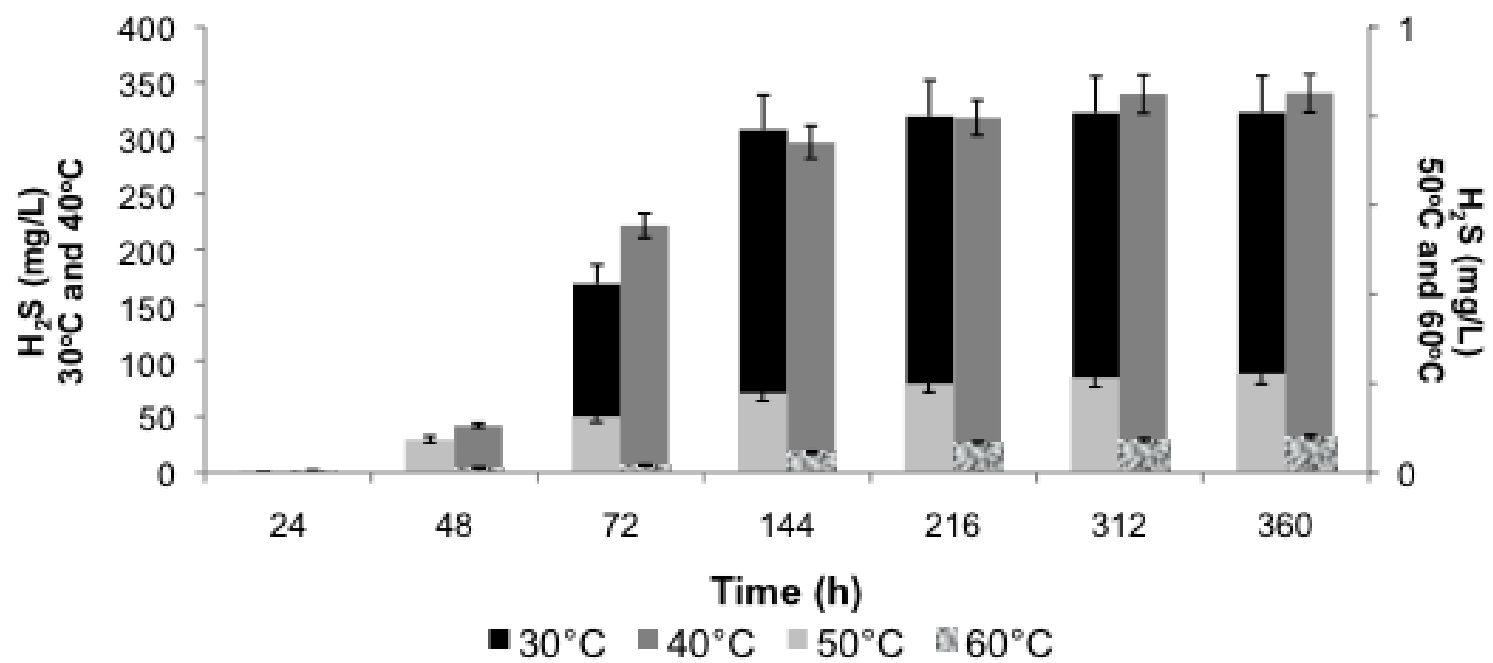

Figure 3. Evaluation of SBA based on the quantification of biogenic sulfide in the sample from the tank A cultured at different temperatures.

produced in 72 hours, exceeding $300 \mathrm{mg} / \mathrm{L}$ after 360 hours. At a temperature of $40^{\circ} \mathrm{C}$, there is also an increase in the production of sulfides at 72 hours reaching $200 \mathrm{mg} / \mathrm{L}$, and, at the end of 360 hours, $350 \mathrm{mg} / \mathrm{L}$ of sulfide had been produced. With temperatures rising to $50^{\circ} \mathrm{C}$ and $60^{\circ} \mathrm{C}$, there was no production of sulfides.

Almeida et al. (2009) observed the growth of SRB in different stages of the treatment of produced water through an analysis of the daily production of sulfide. These authors also examined the direct relationship between the growth of SRB and the corrosive processes that occur in the production lines, associated with the treatment of oil and water on oil rigs. Water samples were collected at three points in the process involving different temperatures. These samples were analyzed for the production of hydrogen sulfide. The highest level of sulfide found was $110 \mathrm{mg} / \mathrm{L}$ within 12 days at a temperature of $40^{\circ} \mathrm{C}$. The tank at a high temperature $\left(90^{\circ} \mathrm{C}\right)$ showed no production of sulfides. Other authors have indicated that SRB are microorganisms, showing reduced kinetics with respect to the transformation of sulfate to sulfide, which are significantly affected by temperature (Stetter et al., 1993; van Houten et al., 1997; Weijma et al., 2000). Moosa et al. (2005) showed a significant increase in the rate of sulfate reduction with an increase in temperature from $20^{\circ} \mathrm{C}$ to $35^{\circ} \mathrm{C}$. Temperatures above $40^{\circ} \mathrm{C}$ decreased the activity of bacteria. In a study by
Bale et al. (1997), SRB were isolated from marine sediments (depth of 80 to $500 \mathrm{~m}$ ) obtained in the sea of Japan. The cultures of the bacteria were, then, incubated using different temperatures (7$70^{\circ} \mathrm{C}$ ) and salinities (0-14\%), and with changes in various factors such as pressure and substrate removal. These SRB produced sulfide over a wide temperature range from $15^{\circ} \mathrm{C}$ to $65^{\circ} \mathrm{C}$, but the temperature associated with the highest activity was $25^{\circ} \mathrm{C}$ within a wide range of sodium chloride concentrations (0.2 to $10 \%)$. This indicates that these microorganisms adapted to diverse conditions. The fact that these authors used SRB isolated from marine sediments are likely to be the main cause to explain the difference between the results obtained in comparison to the ones presented in this work.

\subsection{Microbiological quantification based} on the procedures suggested by Harrigan (1998) and the FDA (2011)

Table 8 presents the data obtained for the MPN of SRB measured at different temperatures $\left(30^{\circ} \mathrm{C}\right.$ to $60^{\circ} \mathrm{C}$ ) in the sample from Tank A. From the results shown in Table 8 , it can be observed that at both temperatures at which bacterial growth was evident, $30^{\circ} \mathrm{C}$ and $40^{\circ} \mathrm{C}$, the quantified values based on Harrigan (1998) were inferior to those obtained based on the FDA method (2011). Considering the measurements produced using the two procedures, it appears that at the two lowest 
Table 8. Quantification of SRB cell numbers at different temperatures.

\begin{tabular}{ccccc}
\hline \multicolumn{5}{c}{ MPN (MPN/mL) - SRB } \\
\hline \multirow{2}{*}{$\begin{array}{c}\text { Temperature } \\
\left({ }^{\circ} \mathrm{C}\right)\end{array}$} & Harrigan & \multicolumn{3}{c}{ FDA } \\
\cline { 3 - 5 } & & Value & Minimum value & Maximum value \\
\hline 30 & $4.50 \times 10^{5}$ & $6.82 \times 10^{8}$ & $3.26 \times 10^{8}$ & $1.43 \times 10^{9}$ \\
40 & $4.50 \times 10^{5}$ & $6.82 \times 10^{8}$ & $3.26 \times 10^{8}$ & $1.43 \times 10^{9}$ \\
50 & 2.50 & 2.85 & 0.60 & 13.50 \\
60 & 2.50 & 2.85 & 0.60 & 13.50 \\
\hline
\end{tabular}

Table 9. Quantification of GAHB cells in different temperatures.

\begin{tabular}{ccccc}
\hline \multicolumn{5}{c}{ MPN (MPN/mL) - GAHB } \\
\hline \multirow{2}{*}{ Temperature $\left({ }^{\circ} \mathrm{C}\right)$} & Harrigan & \multicolumn{4}{c}{ FDA } \\
\cline { 2 - 5 } & & Value & Minimum value & Maximum value \\
\hline 30 & $4.50 \times 10^{6}$ & $2.51 \times 10^{10}$ & $1.30 \times 10^{10}$ & $4.87 \times 10^{10}$ \\
40 & $9.50 \times 10^{6}$ & $3.49 \times 10^{10}$ & $1.83 \times 10^{10}$ & $6.69 \times 10^{10}$ \\
50 & 2.50 & 2.85 & 0.60 & 13.50 \\
60 & 1.10 & 1.10 & 0.35 & 3.48 \\
\hline
\end{tabular}

temperatures, $30^{\circ} \mathrm{C}$ and $40^{\circ} \mathrm{C}$, the MPN values are equal, $4.50 \times 10^{5} \mathrm{MPN} / \mathrm{mL}$ (Harrigan) and $6.82 \times 10^{8} \mathrm{MPN} / \mathrm{mL}(\mathrm{FDA})$, and indicate significant growth of SRB.

In contrast, at higher temperatures, $50^{\circ} \mathrm{C}$ and $60^{\circ} \mathrm{C}$, there was no significant growth of these bacteria. This stagnation demonstrates that bacteria do not adapt to high temperatures; therefore, they are not of thermophilic nature. Study of Benka-Coker et al. (1995) measured SRB in water samples from six different oil fields in the Niger Delta in Nigeria. The study concludes that this group of bacteria predominates at temperatures between $26^{\circ} \mathrm{C}$ and $33^{\circ} \mathrm{C}$ and at $\mathrm{pH}$ levels of 6.1 to 8.1 after 14 days of incubation. Table 9 presents the data obtained from the MPN of GAHB according to both techniques.

It can be observed in Table 9 that the values quantified based on the method of Harrigan were, again, an order of magnitude lower than the values shown in the FDA Table. Growth of GAHB as well as SRB can be observed at lower temperatures. According Harrigan (1998), the highest bacterial growth occurred at a temperature of $40^{\circ} \mathrm{C}(9.50 \mathrm{x}$
$10^{6} \mathrm{MPN} / \mathrm{mL}$ ), which was also the temperature at which the highest growth $\left(3.49 \times 10^{10} \mathrm{MPN} / \mathrm{mL}\right)$ occurred based on the FDA method (2011). However, this latter value $\left(3.49 \times 10^{10} \mathrm{MPN} / \mathrm{mL}\right)$ is equivalent to that observed at $30^{\circ} \mathrm{C}\left(9.50 \times 10^{10}\right.$ $\mathrm{MPN} / \mathrm{mL}$ ). In accordance with the presented results, it can be concluded that the lower temperatures tested encourage the growth of bacteria in such samples. Based on the quantification of SRB, it was observed that the temperatures that promote the growth of these groups were $30^{\circ} \mathrm{C}$ and $40^{\circ} \mathrm{C}$. In the case of GAHB, increased growth was observed at a temperature of $40^{\circ} \mathrm{C}$, based on the statistical analysis provided by the method proposed by Harrigan (1998). According to the method proposed by the FDA, the values found for temperatures of $30^{\circ} \mathrm{C}$ and $40 \circ \mathrm{C}$ were statistically identical. Most species of SRB die rapidly at temperatures above $45^{\circ} \mathrm{C}$ (Postgate, 1984; Widdel, 1988). Okabe and Characklis (1992) reported that the maximum specific growth rate of Desulfovibrio desulphuricans ranged between 0.38 and $0.55 \mathrm{~h}$ at $25^{\circ} \mathrm{C}$ and $43^{\circ} \mathrm{C}$, respectively. For SBA, a temperature of $40^{\circ} \mathrm{C}$ was also found to be the temperature that most favored the evolution of sulfide from the samples. 


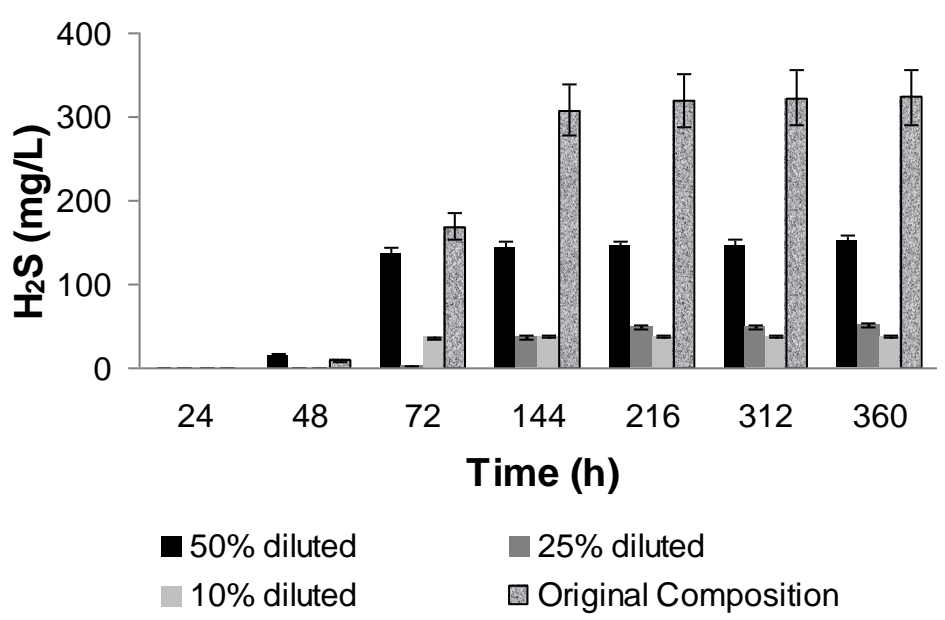

Figure 4. Evaluation of SBA in the sample from the tank using different compositions of culture medium.

\subsection{Effect of the composition of the medium on the generation of biogenic sulfides}

Sulfide production was evaluated at a salinity of $35 \%$ and at a temperature of $40^{\circ} \mathrm{C}$ using the Postgate culture medium diluted to $50 \%, 25 \%$, or $10 \%$ of its original concentration using synthetic sea water. The purpose of diluting the culture medium was to work under conditions that simulate the most conservative marine environment, where the availability of organic matter is significantly compromised. Consequently, it was expected that the production of biogenic sulfides will follow this trend.

In the graph of SBA shown in Figure 4, the concentrations of sulfide produced by the SRB over time at different dilutions of the original culture medium tested are shown. According to Figure 4, a decrease in the concentration of sulfide produced can be observed with a decrease in the concentration of the culture medium. The highest concentration of sulfide accumulated was approximately $140 \mathrm{mg} / \mathrm{L}$, which was obtained using the $50 \%$ culture medium dilution. At this dilution, production of the metabolite was nearly constant from 72 hours to 360 hours. In the $25 \%$ and $10 \%$ dilutions of the medium, sulfide production was lower, as might have been expected, due to the reduced availability of organic matter. In the intermediate dilution of $25 \%$ of the original composition of the medium, sulfide production was first observed at144 hours and remained constant up to 360 hours. In the intermediate $10 \%$ dilution, the production of sulfide could be observed beginning at 72 hours and remained almost constant up to 360 hours. No growth was observed in the saline solution, indicating that the total organic matter was insufficient to reduce the sulfates present. The results followed the expected trend, with decreasing production of biogenic sulfide being observed as the availability of organic matter decreased.

Thus, in accordance with these observations, it can be stated that when the availability of nutrients is reduced, the biogenic production of sulfide also decreases. Therefore, it was expected that a closer composition of media to the marine environment would decrease the production of biogenic sulfide, which would be stimulated under conditions of greater availability of nutrients.

\subsection{Microbiological quantification based on the procedures suggested by Harrigan (1998) and the FDA (2011)}

Table 10 presents data obtained for the MPN of SRB in different dilutions of culture medium (50\%, $25 \%$, and $10 \%$ of the original composition and saline) following the MPN technique considering the values estimated according to Harrigan (1998) and the FDA (2011). 
Table 10. Quantification of SRB cell numbers under different compositions of culture medium.

\begin{tabular}{|c|c|c|c|c|}
\hline \multicolumn{5}{|c|}{ MPN (MPN/mL) - SRB } \\
\hline \multirow[b]{2}{*}{ Culture medium } & \multirow[b]{2}{*}{ Harrigan } & \multicolumn{3}{|c|}{ FDA } \\
\hline & & Value & $\begin{array}{c}\text { Minimum } \\
\text { value }\end{array}$ & $\begin{array}{c}\text { Maximum } \\
\text { value }\end{array}$ \\
\hline $50 \%$ of original composition & $9.50 \times 10^{4}$ & $2.55 \times 10^{7}$ & $1.20 \times 10^{7}$ & $5.42 \times 10^{7}$ \\
\hline $25 \%$ of original composition & $2.50 \times 10^{4}$ & $1.42 \times 10^{7}$ & $6.20 \times 10^{6}$ & $3.28 \times 10^{7}$ \\
\hline $10 \%$ of original composition & 0.70 & 1.10 & 0.35 & 3.48 \\
\hline Saline solution & 0.00 & 0.00 & 0.00 & 0.00 \\
\hline
\end{tabular}

Table 11. Quantification of GAHB cell numbers under different compositions of culture medium.

\begin{tabular}{|c|c|c|c|c|}
\hline \multicolumn{5}{|c|}{ MPN (MPN/mL) - GAHB } \\
\hline \multirow[b]{2}{*}{ Culture medium } & \multirow[b]{2}{*}{ Harrigan } & \multicolumn{3}{|c|}{ FDA } \\
\hline & & Value & $\begin{array}{c}\text { Minimum } \\
\text { value }\end{array}$ & $\begin{array}{c}\text { Maximum } \\
\text { value }\end{array}$ \\
\hline $50 \%$ of original composition & $9.50 \times 10^{4}$ & $2.55 \times 10^{7}$ & $1.20 \times 10^{7}$ & $5.42 \times 10^{7}$ \\
\hline $25 \%$ of original composition & $2.50 \times 10^{4}$ & $1.42 \times 10^{7}$ & $6.20 \times 10^{6}$ & $3.28 \times 10^{7}$ \\
\hline $10 \%$ of original composition & $2.50 \times 10^{4}$ & $1.42 \times 10^{7}$ & $6.20 \times 10^{6}$ & $3.28 \times 10^{7}$ \\
\hline Saline solution & 0.00 & 0.00 & 0.00 & 0.00 \\
\hline
\end{tabular}

It can be observed from the results shown in Table 10 that decreases in the concentration of the culture medium also reduce microbial growth. In the two compositions at which bacterial growth was evident ( $50 \%$ and $25 \%$ of the composition), the values quantified based on the method of Harrigan (1998) were also lower than those obtained using the FDA method (2011), as observed in previous trials. Using the procedure proposed by Harrigan (1998), the highest growth was determined to occur in the least diluted medium $\left(9.50 \times 10^{4}\right.$ $\mathrm{MPN} / \mathrm{mL}$ ). When the medium was at $25 \%$ of its original composition, the concentration of SRB was $2.50 \times 10^{4} \mathrm{MPN} / \mathrm{mL}$. The values obtained according to the FDA method (2011) for these two concentrations were statistically equivalent because of the lower and upper limits established in this method. When the medium was used at $10 \%$ of its original composition, there was no significant microbial growth determined using the methods proposed by both Harrigan (1998) and the FDA (2011). When saline alone was used in place of the medium, no growth of SRB was detected. When the culture medium was used at a higher concentration ( $50 \%$ of the original composition), increased growth of SRB was detected due to the increased availability of nutrients.

Table 11 presents data obtained for the GAHB MPN according to the methods of Harrigan (1998) and the FDA (2011), using the same dilutions of the culture medium $(50 \%, 25 \%$, and $10 \%$ of the original composition or saline solution). As shown in previous analyses, Table 11 indicates that the values obtained using the Harrigan method were an order of magnitude lower than those obtained via the FDA method. The greatest amount of GAHB growth $\left(9.50 \times 10^{4} \mathrm{MPN} / \mathrm{mL}\right)$ was observed when using the most concentrated dilution of the medium ( $50 \%$ of the original composition), while in the more diluted media $(25 \%$ and $10 \%$ of the original composition), the concentration was equal to $2.50 \times 10^{4} \mathrm{MPN} / \mathrm{mL}$ (Harrigan, 1998).

The values based on FDA recommendations indicated that the highest GAHB concentration $\left(2.55 \times 10^{7} \mathrm{MPN} / \mathrm{mL}\right)$, observed in the least diluted medium ( $50 \%$ of the composition), was statistically equal to the values found for the two most diluted concentrations $\left(1.42 \times 10^{7} \mathrm{MPN} / \mathrm{mL}\right)$. Similarly, when saline alone was used in place of the 
medium, no microbial growth was detected. Growth of GAHB cells at $50 \%, 25 \%$, and $10 \%$ of the original composition of the culture medium indicated that these bacteria are capable of growing in spite of the low availability of nutrients, which was confirmed in the intermediate dilution of $10 \%$ of the original composition.

Based on SBA, the negative effect of the reduction of nutrients in the culture medium on the production of biogenic sulfide was observed more clearly. Thus, it can be inferred that in the marine environment, where the availability of organic matter is very low, the production of sulfide is minimized. Though there are latent populations of GAHB and SRB in such environments, there is no energy source available for the reduction of sulfate. However, when these oil/water samples are removed from the seabed and stored in tanks together with a number of other chemicals, where there is an increased amount of organic material present, the production of sulfide is catalyzed in a sequence following the activity of GAHB. This biogenic sulfide production is therefore anthropogenically stimulated, rather than naturally occurring. It can be concluded from the tests performed here that the production of biogenic sulfide is optimal under a salinity of $35 \mathrm{~g} / \mathrm{L}$ at $40^{\circ} \mathrm{C}$ in nutritional conditions ranging from a $25 \%$ dilution of the culture medium to $100 \%$ Postgate medium. Under these conditions, high yields of sulfides were observed as well as high concentrations of GAHB. Concentrations of SRB, not always associated with the observed production or correlated with biogenic GAHB, were examined. Thus, rather than just representing adequate conditions for the production of biogenic sulfide, environmental conditions may be optimized in tanks storing the samples to make available the organic substrate capable of catalyzing the production of biogenic sulfide, which is not always related to the total microbial population present.

\section{CONCLUSIONS}

The conditions, with respect to the microbial population and the biogenic production of sulfide, are not equivalent in all of the investigated storage tanks for water and oil. This indicates that heterogeneity can be expected in such an environment. It was observed that with the increase in salinity levels, microbial growth and biogenic sulfide generation were decreased. It was also found that temperature has an adverse effect on the biogenic production of sulfide in samples from storage tanks for water and oil. Regarding the composition of the medium, it can be observed that, when the medium is more dilute in a tank, i.e., closer to the composition of seawater, the biogenic production of sulfide is reduced due to the lack of nutrients available for SRB. With respect to the technique used for quantifying SRB and GAHB, it was found that there was not always a direct relationship between the microbial population and the biogenic production of sulfide, or with regard to the temperature and the composition of the salinity of the medium. The MPN technique, based on procedures presented in the literature, proved to produce different results when considering absolute values or values including error estimates. In general, the MPN technique, grounded on absolute values, underestimates the microbial populations typical of this type of sample. It can be concluded that quantification of biogenic sulfide was found to be a faster and more reliable and accurate indicator for the evaluation of microbiological activity in samples collected from the bottom of a tank containing oil and water. The MPN technique is more laborious and inaccurate and does not always present a homogeneous growth profile that would allow a clear understanding of the consequences of the presence of these species in such samples.

\section{ACKNOWLEDGEMENTS}

The authors would like to thank CNPq and Faperj for the support to conduct this work.

\section{REFERENCES}

Agrawal, A.; Vanbroekhoven, K.; Lal, B. Diversity of culturable sulfidogenic bacteria in two oil-water separation tanks in the north-eastern oil fiels of India. Anaerobe, v.16, p. 12-18, 2010. http://dx.doi.org/10.1016/i.anaerobe.2009.04.005 
Almeida, E. S. C.; Freire, M. G. M.; Rabelo, S. K. L. Avaliação dos Efeitos da presença de bactérias redutoras de sulfato em linhas de produção de petróleo na Bacia de Campos. Perspectivas Online, v. 3, 2009, 19p. (In Portuguese)

Andrade, C. A.; Paiva, E. M. O; Penna, M. O.; Santanna, L. M. M. Seleção de tratamento químico para controle da corrosão em resfriadores de gás de turbo compressores de plataformas marítimas da Petrobras. In: Proceedings of 60 CONTEQ, Salvador - BA, 2002. (In Portuguese)

APHA, AWWA, WEF. Standard Methods for the Examination of Water and Wastewater, Washington, 20 ${ }^{\text {th }}$ Edition, 1998.

Bale, J. S.; Goodman. P; Rochelle, P. A.; Marchesi, J. R.; Fry, J. C.; Wwightman, A. J.; Pares, R. J. Desulfovibrio profundus sp. nov., a novel barophilic sulfate-reducing bacterium from deep sediment layers in the Japan Sea. International of Systematic Bacteriology, v. 47, p. 515-521, 1997. http://dx.doi.org/10.1099/00207713-47-2-515

Benka-Coker, M.O.; Metseagharum, W.; Ekundayo, J. A. Abundance of sulphate-reducing bacteria in Niger Delta oilfields waters. Bioresource Technology, v.54, p.151-154, 1995.

http://dx.doi.org/10.1016/0960-8524(95)00118-2

Brandt, K. K.; Vester, F.; Jensen, A. N.; Ingvorsen, $K$. Sulfate reduction dynamics and enumeration of sulfate-reducing bacteria in hypersaline sediments of the Great Salt Lake (Utah, USA). Microbial Ecology, v. 41, p. 1-11, 2001.

FDA, Food and Drug Administration (2011) Bacteriological Analytical Manual - Appendix 2: Most Probable Number from serial dilutions. Available at:

www.fda.gov/Food/ScienceResearch/LaboratoryMethod s/BacteriologicalAnalyticalManualBAM/ucm109656.htm

Grassia, G. S.; Mclean, K. M.; Glenat, P.; Bauld, J.; Sheehy, A. J. A systematic survey for thermophilic fermentative bacteria and archaea in high temperature petroleum reservoirs. Fems Microbiology Ecology, v.21, p. 47-58, 1996. http://dx.doi.org/10.1111/j.1574-6941.1996.tb00332.x

Harrigan, W.F. Laboratory Methods in Food Microbiology. USA: Academic Press, p. 532, 1998.
Madigan, M. T.; Martinko, J. M.; Dunlap, P. V.; Clark, D. P. Microbiologia de Brock. Ed. Artmed, 12a edição, 2010. (In Portuguese)

McCrady, M. H. The numerical interpretation of fermentation-tube results. Journal of Infectious Diseases, v. 17, p. 183-212, 1915. http://dx.doi.org/10.1093/infdis/17.1.183

Moosa, M.; Nemati, M.; Harrison, S. T. L. A kinetic study on anaerobic reduction of sulphate. Part II. Incorporation of temperature effects in the kinetic model. Chemical Engineering Sciences, v. 60, p. 3517-3524, 2005.

http://dx.doi.org/10.1016/i.ces.2004.11.036

Okabe, S.; Characklis, W.G. Effects of temperature and phosphorus concentration on microbial sulphate reduction by Desulfovibrio desulphuricans. Biotechnology and Bioengineering, v. 39, p. 1031-1042, 1992. http://dx.doi.org/10.1002/bit.260391007

Penna, M. O.; Oliveira, H. B.; Silva, E. D. Avaliação da Atividade Metabólica (Produção de $\mathrm{H}_{2} \mathrm{~S}$ ) de culturas mistas de bactérias Redutoras de sulfato (BRS). Boletim Técnico da Petrobras, v. 46, p 208-219, 2003. (In Portuguese)

Postgate, J.R, The sulphate-reducing bacteria. $2^{\text {a }}$ ed., Cambridge University Press, Cambridge, England, 1984.

Sant'Anna, G. S.; Tristão, M. L.; Nascimento, J. R.; da Costa, A. C. A. Estudo de parâmetros ambientais para classificação de tanques de armazenamento de óleo. Petro \& Química, v. 310, p. 1-8, 2008. (In Portuguese)

Shpiner, R.; Liu, G.; Stuckey, D. C., Treatment of oilfield produced water by waste stabilization ponds: Biodegradation of petroleum-derived materials. Bioresource Technology, v. 100, p. 62296235, 2009.

http://dx.doi.org/10.1016/i.biortech.2009.07.005

Silva, C. R. R.; Água Produzida na Extração do Petróleo - Curso de Especialização em Gerenciamento e Tecnologias ambientais na Indústria - Escola Politécnica - Universidade Federal da Bahia, 2000. (In Portuguese) 
Stetter, K. O.; Huber, R.; Blöchl, E.; Kurr, M.; Eden, R. D.; Fielder, M.; Cash, H.; Vance, I. Hyperthemophilic archaea are thriving in the deep north sea and Alaskan oil reservoirs, Nature, v. 365, p. 743-745, 1993.

http://dx.doi.org/10.1038/365743a0

Thomas, J. E.; Triggia, A. A.; Correia, C. A.; Filho, C. V.; Xavier, J. A. D.; Machado, J. C. V.; de Paula, J. L.; de Rossi, N. C. M.; Pitombo, N. E. S.; Gouvea, P. C. V. M.; Carvalho, R. S.; Barragan, R. V. Fundamentos de Engenharia de Petróleo, 2a Ed., Rio de Janeiro: Interciência, PETROBRAS, 2004. (In Portuguese)

Van Houten, R. T.; Yun, S. Y.; Lettinga, G. Thermophilic sulphate and sulphite reduction in lab-scale gas-lift reactors using $\mathrm{H}_{2}$ and $\mathrm{CO}_{2}$ as energy and carbon source. Biotechnology and Bioengineering, v. 55, p. 807-814, 1997. http://dx.doi.org/10.1002/(SICI)10970290(19970905)55:5<807::AID-BIT11>3.0.CO;2-8

Vazoller, R. F. Características e interações microbianas nos processos de tratamento biológico aeróbio e anaeróbio. In: Curso de Processos Biológicos de Tratamento de Resíduos, 2., Instituto de Pesquisas Tecnológicas do Estado de São Paulo. 1993, 18p. (In Portuguese)
Videla, H. A. Biocorrosão, Biofouling e biodeterioração de materiais. Editora Edgard Blucher, 2003. (In Portuguese)

Vieira, D. S.; Cammarota, M. C.; Camporese, E. F. S., Redução de contaminantes presentes na água de produção de petróleo. In: 2‥ Congresso Brasileiro de P\&D em Petróleo e Gás, Rio de Janeiro, UFRJ, 2011. (In Portuguese)

Weijma, J.; Stams, A.J.M.; Hulshoff POL, A.W.; Lettinga, G. Thermophilicsulphate reduction and methanogenesis with methanol in a high rate anaerobic reactor, Biotechnology and Bioengineering, v. 67, p. 354-363, 2000. http://dx.doi.org/10.1002/(SICI)10970290(20000205)67:3<354::AID-BIT12>3.0.CO;2-X

Widdel, F. Microbiology and Ecology of Sulphate and Sulphur-Reducing Bacteria. In: A.J.B. Zehnder (ed.) Biology of Anaerobic Microorganisms. Wiley, New York, 1988. 